\title{
Characterization of indigenous barberry germplasm in Pakistan: variability in morphological characteristics and nutritional composition
}

\author{
Maqsood AHMED ${ }^{1}$, Muhammad Akbar ANJUM ${ }^{2}$, Raja Mohib Muazzam NAz ${ }^{3}$, Muhammad Riaz KHAN ${ }^{3}$, Sajjad HuSSAIN ${ }^{2^{*}}$
}

\author{
${ }^{1}$ Dep. Biotechnol., Mirpur \\ Univ. Sci. Technol., Mirpur, \\ Azad Jammu \& Kashmir, \\ Pakistan \\ 2 Dep. Hortic., Bahauddin \\ Zakariya Univ., Multan 60000, \\ Pakistan, sajjad_h@yahoo.com \\ ${ }^{3}$ Dep. Hortic., Fac. Agric., \\ Univ. Poonch, Rawalakot, \\ Azad Jammu \& Kashmir, \\ Pakistan
}

${ }^{*}$ Correspondence and reprints

Received 26 September 2012 Accepted 20 December 2012

Fruits, 2013, vol. 68, p. 409-422 (C) 2013 Cirad/EDP Sciences All rights reserved

DOI: $10.1051 /$ fruits/2013085

www.fruits-journal.org

RESUMEN ESPAÑOL, p. 422
Characterization of indigenous barberry germplasm in Pakistan: variability in morphological characteristics and nutritional composition.

Abstract - Introduction. Barberry (Berberis aristata DC.), a small fruit, is found growing in the wild in the temperate region of northern Pakistan. Materials and methods. Three different locations of Azad Jammu and Kashmir, i.e., Topa, Banjosa and Neriyan Sharif, were explored; thirty accessions of barberry were identified and characterized on the basis of their growth habit, flowering, fruiting and chemical composition of fruits. Results. The accessions exhibited high diversity in their phenotypical/morphological traits such as growth habit, intensity and time of flowering, fruit setting, ripening time, productivity, and fruit shape and color. The location had a great impact on quantitative parameters. Accessions collected from Neriyan Sharif had significantly greater plant height, higher number of branches per plant, extended flowering duration (days), took more time to maturity (days) and had high fruit setting (\%), while those from Topa had large-sized leaves and fruits with greater average fruit weight. The nutritional composition of fruits indicated that the accessions from Topa had higher carbohydrate, ash, total soluble solids and Mn contents, with significantly higher juice $\mathrm{pH}$, and lower acidity; while the accessions from Neriyan Sharif had significantly higher moisture, protein, fat, fiber, $\mathrm{K}, \mathrm{Ca}, \mathrm{Na}, \mathrm{Fe}, \mathrm{Cu}, \mathrm{Pb}$ and $\mathrm{Cr}$ contents and were highly acidic. The accessions collected from Banjosa were almost intermediate for the quantitative characteristics studied. Conclusions. The results suggested that not only the genotype but its growing location as well are the main factors that determine the growing habit, productivity and nutritional composition of barberry fruits, and this ultimately provides important information on how to make the best use of them.

Pakistan / Berberis aristata / biodiversity / fruits / physicochemical properties / proximate composition / genotype environment interaction

Caractérisation du matériel génétique indigène de l'épine-vinette au Pakistan : variabilité des caractéristiques morphologiques et de la composition nutritionnelle.

Résumé - Introduction. L'épine-vinette (Berberis aristata DC.), qui produit de petits fruits, se développe à l'état sauvage dans la zone tempérée du nord du Pakistan. Matériel et méthodes. Trois localités différentes (Topa, Banjosa et Neriyan Sharif) de l'Azad Jammu-et-Cachemire ont été explorées ; trente accessions d'épine-vinette ont été identifiées et caractérisées sur la base de leur port, floraison, fructification et composition chimique des fruits. Résultats. Les accessions étudiées ont présenté une forte diversité de caractéristiques phénotypiques et morphologiques (port, intensité et durée de floraison, nouaison, maturation, productivité, forme et couleur du fruit). La localisation a eu une grande incidence sur les paramètres quantitatifs. Les accessions collectées auprès de Neriyan Sharif ont significativement présenté de plus grands plants, un plus grand nombre de branches par plant, une durée de floraison plus longue, un temps de maturation plus long et ont eu un fort taux de nouaison, alors que les fruits collectés à Topa ont eu des feuilles plus grandes et des fruits de forts poids moyens. La composition nutritionnelle des fruits a révélé que les accessions de Topa produisaient des fruits à plus fortes teneurs en glucides, cendres, solides solubles totaux et Mn avec un jus à pH élevé et acidité faible, tandis que les fruits des accessions de Neriyan Sharif présentaient des taux significativement plus élevés en humidité, protéines, lipides, fibres, $\mathrm{K}, \mathrm{Ca}, \mathrm{Na}, \mathrm{Fe}, \mathrm{Cu}, \mathrm{Pb}$ et teneurs en $\mathrm{Cr}$, et étaient très acides. Les accessions collectées auprès de Banjosa ont été à peu près intermédiaires pour les caractéristiques quantitatives étudiées. Conclusions. Nos résultats suggèrent que non seulement le génotype mais aussi son lieu de culture sont les principaux facteurs qui déterminent le port, la productivité et la composition nutritionnelle des fruits de l'épine-vinette ; globalement ces informations importantes pourront permettre d'optimiser leur utilisation.

Pakistan / Berberis aristata / biodiversité / fruits / propriété physicochimique / composition globale / interaction génotype environnement 


\section{Introduction}

The genus Berberis belonging to the family Berberidaceae is widely distributed in temperate and sub-tropical regions of the Northern Hemisphere and temperate South America [1]. It has about 650 species worldwide, of which 54 species have been reported from the Indian Himalayas. Barberry (Berberis aristata DC.), a spiny shrub, 1.8$3.6 \mathrm{~m}$ in height, is abundantly found growing in the wild in the whole range of the Himalaya Mountains up to an elevation of $3300 \mathrm{~m}$. The fruit is a small, $7-10 \mathrm{~mm}$ - long, spherical, oblong or ovate berry. Berberis aristata, popularly known as 'Daruhaldi' and commonly known in different areas as 'garhwal', 'chitri' and 'sumbal', has diverse uses such as the fruits, which are edible and consumed; branches, which are used as fuel wood; leaves, as fodder for goats, and the whole plant, as a live fence or hedge $[2,3]$. The berries are rich in vitamin $\mathrm{C}$, with a very sharp flavor. In India, the fruits are sometimes sold in local markets [4]. The dried fruits are also used as herbal medicine. The active ingredients in the barberry stem and root bark are thought to be the isoquinoline alkaloids, especially berberine. For the first time, Saied et al. identified four alkaloids, (pakistanine, 1-O-methylpakistanine, pseudopalmatine chloride and pseudoberberine chloride) from Berberis aristata [5]. It is a mild laxative, a tonic, is useful in curing ulcers and fevers, and also useful in treating anorexia, dysentery, hepatitis and liver disorders [6]. The root is used as a medicine by local inhabitants. In its efficacy, it is almost equal to quinine and Warburg's tincture and does not produce any bad effects on the stomach, bowel, brain or organs of hearing [7]. The fruits of Berberis species are eaten by the villagers in the hills and also offered for sale at some places, mostly near schools, because they are very much liked by children due to their taste. Berberis fruits have extractable juice $26.6 \%$, moisture $63.4 \%$, TSS $18.90 \%$, acidity $1.07 \%$, total sugar $11.97 \%$, pectin $0.37 \%$, and vitamin $\mathrm{C}$ content $4.60 \mathrm{mg} \cdot 100 \mathrm{~mL}^{-1}$ of juice; minerals such as potassium, calcium, sodium and iron are present in various quantities [4]
Variability in fruit characteristics of wild and primitive varieties of temperate fruits have been reported by various authors [811]. Barberry represents a large proportion of small fruit plants. Maikhuri et al. [12] stated that the genus Berberis, abundantly found on both sides of the Himalayas as a wild fruit and in semi-domesticated form, had high potential for exploitation. Both forms are found growing in the wild in the mountainous area of Poonch division of Azad Jammu \& Kashmir (northern Pakistan). Rawalakot valley lies at an altitude of 1800$2100 \mathrm{~m}$ and at a latitude of $33-36^{\circ}$ under the foothills of the Himalayas. The climate of the area is temperate and sub-humid, with annual rainfall ranging from about 500$2000 \mathrm{~mm}$, most of which is irregular, with intensive storms during monsoon and winter. The mean annual temperature ranges from a few degrees below $0{ }^{\circ} \mathrm{C}$ to a maximum of $30{ }^{\circ} \mathrm{C}$ accompanied by severe cold and snowfall in winter [13].

Underexploited and underutilized natural resources, including wild fruits, with potential economic importance play a vital role in maintaining the subsistence lifestyle in traditional mountain societies. The wild fruits of many species have served as a source of food and medicine for thousands of years, particularly in the tribal and rural areas of the Himalayas [14], and barberry fruit is one of those. Characterization of wild germplasm holds promise for improving existing material, which in turn will cause local- and national-based quality products to flourish.

The objective of our study was to compare the physicochemical properties of indigenous germplasm of barberry (B. aristata DC.) found growing in the wild in the temperate region of northern Pakistan. This research on characterization of wild and local germplasm of barberry will increase our knowledge about its future utilization.

\section{Materials and methods}

\subsection{Plant material and ecological characteristics of the locations}

Thirty genotypes of barberry (B. aristata DC.) collected from three different locations 
of Azad Jammu and Kashmir (Pakistan), i.e. Topa (TP), Banjosa (BG) and Neriyan Sharif (NS), were used for this study.

\subsubsection{Topa location}

Elevation ranges from $1674 \mathrm{~m}$ to $1981 \mathrm{~m}$ from sea level. There are tops with steep slopes towards the northern side. Winter temperatures range from $-5{ }^{\circ} \mathrm{C}$ to $5^{\circ} \mathrm{C}$ with severe snowfall during late December to late February, or sometimes in early March. Summer (April to September) temperatures range from $6^{\circ} \mathrm{C}$ to $22^{\circ} \mathrm{C}$.

\subsubsection{Banjosa location}

Elevation ranges from $1219 \mathrm{~m}$ to $1828 \mathrm{~m}$ from sea level. There are depressions with gentle slopes from all sides. Winter temperatures range from $-2{ }^{\circ} \mathrm{C}$ to $9{ }^{\circ} \mathrm{C}$ with moderate snowfall during January. Summer temperatures range from $12{ }^{\circ} \mathrm{C}$ to $28{ }^{\circ} \mathrm{C}$.

\subsubsection{Neriyan Sharif location}

Elevation ranges from $1219 \mathrm{~m}$ to $1981 \mathrm{~m}$ from sea level. Southern and eastern slopes are exposed to sunlight. Winter temperatures range from $-1{ }^{\circ} \mathrm{C}$ to $10^{\circ} \mathrm{C}$, and snowfall occurs during January but, due to being exposed from all sides, it melts immediately. Summer temperatures range from $12{ }^{\circ} \mathrm{C}$ to $30{ }^{\circ} \mathrm{C}$.

\subsection{In situ qualitative evaluation}

A comprehensive survey of the three locations mentioned above was conducted. Thirty plants found growing in the wild in these areas were selected and labeled for data collection. In situ investigations were recorded on the growth habit of plants, intensity and time of flowering, fruit setting, ripening time, productivity, fruit shape, and exterior color of immature and mature fruits. The color of the fruits was recorded according to the horticultural color chart issued by the Royal Horticultural Society, London, UK [15].

\subsection{Quantitative evaluation of morphological traits}

Phenotypic/morphological characteristics of the accessions such as plant height, number of branches per plant, leaf size (length and width), fruit setting \%, flowering duration, days to fruit maturity, fruit size (length and width) and weight were studied during the course of time. Plant height was measured from the ground level to the top of the plant with the help of a measuring tape. Number of branches per plant was counted randomly from the selected plants from each location and their averages were calculated. Leaf length and width were measured with the help of a leaf area meter. Duration of flowering was recorded from the date of opening of the first flower to the date of dropping of the last petal of each accession, as described by Singh et al. [16]. Fruit setting was recorded by counting the total number of flowers and visually observing the number of flowers developing into fruits. Days to fruit maturity were counted from the first day of fruit set to the date of fruit maturity for the accessions of the three locations. For estimation of fruit size (length and width) and fruit weight, ripe fruits were randomly collected from the plants of each location. Average fruit length and width were measured by using a Vernier caliper and average fruit weight was recorded using an electric balance.

\subsection{Chemical analysis}

Fully ripe fruits were harvested from each location and were stored in an icebox to avoid physicochemical changes during transportation from the field area to the laboratory for chemical analysis. The edible portion (pulp) or juice of the fruits was analyzed for various parameters as described below.

\subsubsection{Moisture content}

Moisture contents of the fruit edible portion were determined by the gravimetric method [17]. One gram of sample was taken in a pre-weighed dried Petri dish $\left(\mathrm{W}_{1}\right)$ and placed in a hot air oven at $105^{\circ} \mathrm{C}$ for $24 \mathrm{~h}$. The sample was removed from the oven and cooled in a desiccator to room temperature and re-weighed $\left(\mathrm{W}_{2}\right)$. The moisture percentage in the sample was determined by using the following formula: Moisture $\%=\left[\left(\mathrm{W}_{1}-\mathrm{W}_{2}\right) / \mathrm{W}_{1}\right] \times 100$. 


\subsubsection{Carbohydrate}

Total soluble carbohydrates were determined by using a spectrophotometer [18] One gram of well-mixed sample of pulp was taken in a $100-\mathrm{mL}$ conical flask. Ten $\mathrm{mL}$ of distilled water was added to the flask with gentle mixing followed by addition of $15 \mathrm{~mL}$ perchloric acid (52\%). The mixture was stirred for $30 \mathrm{~min}$ and filtered through a No. 1 Whatman filter. One $\mathrm{mL}$ of the filtrate was drawn into a test tube followed by addition of anthrone reagent $(4 \mathrm{~mL})$. Absorbance was measured at a wavelength of $620 \mathrm{~nm}$ by using a spectrophotometer. Total soluble carbohydrates were determined by drawing a standard curve of glucose.

\subsubsection{Crude protein}

Crude protein estimation was performed by using the Kjeldahl digestion and distillation method [17]. Up to $1 \mathrm{~g}$ of the sample along with $5.5 \mathrm{~g}$ digestion mixture $\left(5 \mathrm{~g} \mathrm{~K}_{2} \mathrm{SO}_{4}\right.$ and $0.5 \mathrm{~g} \mathrm{CuSO}_{4}$ ) was taken in a round-bottomed long-neck flask. Sulfuric acid $(25 \mathrm{~mL})$ was taken into the digestion flask and the sample was digested until the digested material became transparent. The flask was cooled and transferred to a $250-\mathrm{mL}$ volumetric flask, and the volume was made up to the mark with distilled water. Distillation of the diluted sample was carried out in a Kjeldahl distillation unit by using $25 \mathrm{~mL}$ $\mathrm{NaOH}$ (40\%). Ammonia liberated from the sample during steam distillation was collected in $4 \%$ boric acid solution and titration was carried out against $0.1 \mathrm{~N} \mathrm{HCl}$ solution. A blank was also run without a sample in the same manner and the crude protein was estimated by using the following formula: Crude $\operatorname{protein} \%=\{[$ (Titer reading with sample - Titer reading with blank) $\times 14 \times 6.25$ ] $/$ Weight of sample\} $\times 100$.

\subsubsection{Crude fat}

The crude fat percentage was determined by the solvent extraction method deploying soxhlet apparatus [17]. Briefly, one g predried sample was taken in a Whatman extraction thimble and covered from the top with a cotton plug. Petroleum ether $(50 \mathrm{~mL})$ was taken in a receiving flask and the thimble was kept in the extraction tube. Both the extraction tube and the receiving flasks were connected with the apparatus and the extraction was carried out for $30 \mathrm{~min}$ followed by rinsing for a period of $1.5 \mathrm{~h}$. After the completion of rinsing, the thimble was removed and the solvent was recovered in the extraction tube. Extracted fat in the receiving flask was placed in a pre-weighed Petri dish and oven-dried at $110{ }^{\circ} \mathrm{C}$ for $1 \mathrm{~h}$. The crude fat percentage was determined after cooling of the Petri dish by using the following formula: Crude fat $\%=($ Weight of extracted fat / Weight of sample) $\times 100$.

\subsubsection{Crude fiber}

Crude fiber contents of the samples were determined by the Official Methods of Analysis [17]. One gram of pre-dried, defatted sample was taken in a glass beaker and $200 \mathrm{~mL}$ of $1.25 \%$ boiling sulfuric acid was added to it. Digestion was carried out at boiling temperature for a period of $30 \mathrm{~min}$ and the acid was drained by filtration through a filtration assembly. The residues on the filter paper were washed with boiling distilled water to remove the traces of acid. After washing, two hundred $\mathrm{mL}$ of $1.25 \% \mathrm{NaOH}$ were added to the residues. The digestion was carried out for the next $30 \mathrm{~min}$ and the alkali was drained by filtration. The residues were again washed with boiling distilled water. The residues were dried overnight in a hot air oven at $110{ }^{\circ} \mathrm{C}$. The sample was cooled in a desiccator and weighed. Incineration of the weighed sample was carried out at $550^{\circ} \mathrm{C}$ in a muffle furnace until gray ash for a period of about $2 \mathrm{~h}$. The crucible was cooled in a desiccator and re-weighed. Crude fiber contents were determined by using the following formula: Crude fiber $\%=$ [(Weight of digested sample - Weight of ash) / Weight of sample] $\times 100$.

\subsubsection{Ash}

Total inorganic matters (ash percentage) were determined by incinerating the sample at $600{ }^{\circ} \mathrm{C}$ [17]. A one-gram sample was weighed in a pre-weighed crucible and the sample was charred to remove smoke and smell at the flame. Incineration of the charred sample was performed in a muffle furnace at $600{ }^{\circ} \mathrm{C}$ for $3 \mathrm{~h}$. After completion of the incineration period, samples were 
removed from the furnace and kept in desiccators, and re-weighed on cooling. Ash percentage was determined by using the following formula: Ash $\%=$ (Weight of ash / Weight of sample) $\times 100$.

\subsubsection{Total soluble solids}

Total soluble solids were determined by using a hand refractometer at $20^{\circ} \mathrm{C}$ as described by the Official Methods of Analysis [17]. One drop of the extracted juice was placed on the absolutely dry prism of the refractometer and the reading was recorded in ${ }^{\circ}$ Brix.

\subsubsection{Juice acidity}

Titratable acidity was determined by the method as described by the Official Methods of Analysis [17]. Well-mixed extracted juice $(10 \mathrm{~mL}$ ) was diluted to $100 \mathrm{~mL}$ in a 250 $\mathrm{mL}$ flask with boiled or neutralized water. A few drops of indicator (phenolphthalein) were added to the diluted sample and titration was carried out against $0.1 \mathrm{~N} \mathrm{NaOH}$ up to the pink end point persisting for at least $30 \mathrm{~s}$. Acidity was calculated by using the following formula: Acidity $\%=(0.1 \times$ Eq weight of acid $\times \mathrm{N}$ of $\mathrm{NaOH} \times$ Titer volume) / Weight of sample] $\times 100$.

\subsubsection{Juice $\mathrm{pH}$}

$\mathrm{pH}$ of the juice sample was recorded with the help of a digital pH meter.

\subsubsection{Mineral detection}

The minerals of the fruit pulp were determined by using an Atomic Absorption Spectrophotometer (AAS iCE 3300, Thermo Scientific, USA) as described by the Approved Methods of the American Association of Cereal Chemists [19]. Briefly, a sample of $0.5 \mathrm{~g}$ was digested separately by the wet digestion method. The sample was first digested with $10 \mathrm{~mL} \mathrm{HNO}_{3}$ at a temperature of $60-70{ }^{\circ} \mathrm{C}$ for $20 \mathrm{~min}$. Further digestion was carried out with $\mathrm{HClO}_{4}$ at a temperature of $190^{\circ} \mathrm{C}$ until the solution became clear. The digested samples were transferred to a 250-mL volumetric flask, the volume was made up with distilled water and filtration was carried out to remove any suspended residues. Analysis was carried out for the estimation of $\mathrm{Fe}, \mathrm{Cu}, \mathrm{Zn}, \mathrm{Mn}, \mathrm{Pb}$ and $\mathrm{Cr}$ $\left(\mathrm{mg} \cdot \mathrm{kg}^{-1}\right)$. Electrolytes, i.e., K, $\mathrm{Ca}$ and $\mathrm{Na}$ $\left(\mathrm{mg} \cdot \mathrm{kg}^{-1}\right)$ from the digested samples, were determined by flame photometry.

\subsection{Statistical analysis}

The quantitative data were analyzed by using one-way analysis of variance (ANOVA). Mean values were compared by employing the least significant difference (LSD) test. All analyses were performed using MSTATC software and differences at the 5\% level $(p<0.05)$ were considered statistically significant.

\section{Results and discussion}

\subsection{Qualitative traits}

In situ qualitative evaluations were made visually by establishing the raspberry descriptor for the parameters, i.e., growth habit of plants, intensity and time of flowering, fruit setting, ripening time, productivity, fruit shape, and exterior color of immature and mature fruits (table $I$ ); the frequency of qualitative traits was calculated (table II).

Out of thirty accessions (10 from each location), fifteen (50\%) had an upright growth habit, seven (23.3\%) had a pyramidal habit and eight $(26.7 \%)$ had a broadspreading growth habit. Intensity of flowering was high in thirteen accessions (43.3\%). In only five accessions (16.7\%) was the intensity of flowering low and the twelve other accessions (40\%) were in the middle for this parameter (figure 1). A total of thirteen accessions (43.3\%) flowered in the middle of the flowering season, which started from mid-March to the first week of April. There were only five accessions (16.7\%) which were late-flowering, i.e., from the second week of April to the last week of April. The remaining accessions, however, overlapped each other to some extent and were early- or early- to mid-season-flowering. Fourteen accessions (46.7\%) had high fruit set. In twelve accessions (40\%), the fruit set was intermediate, while 


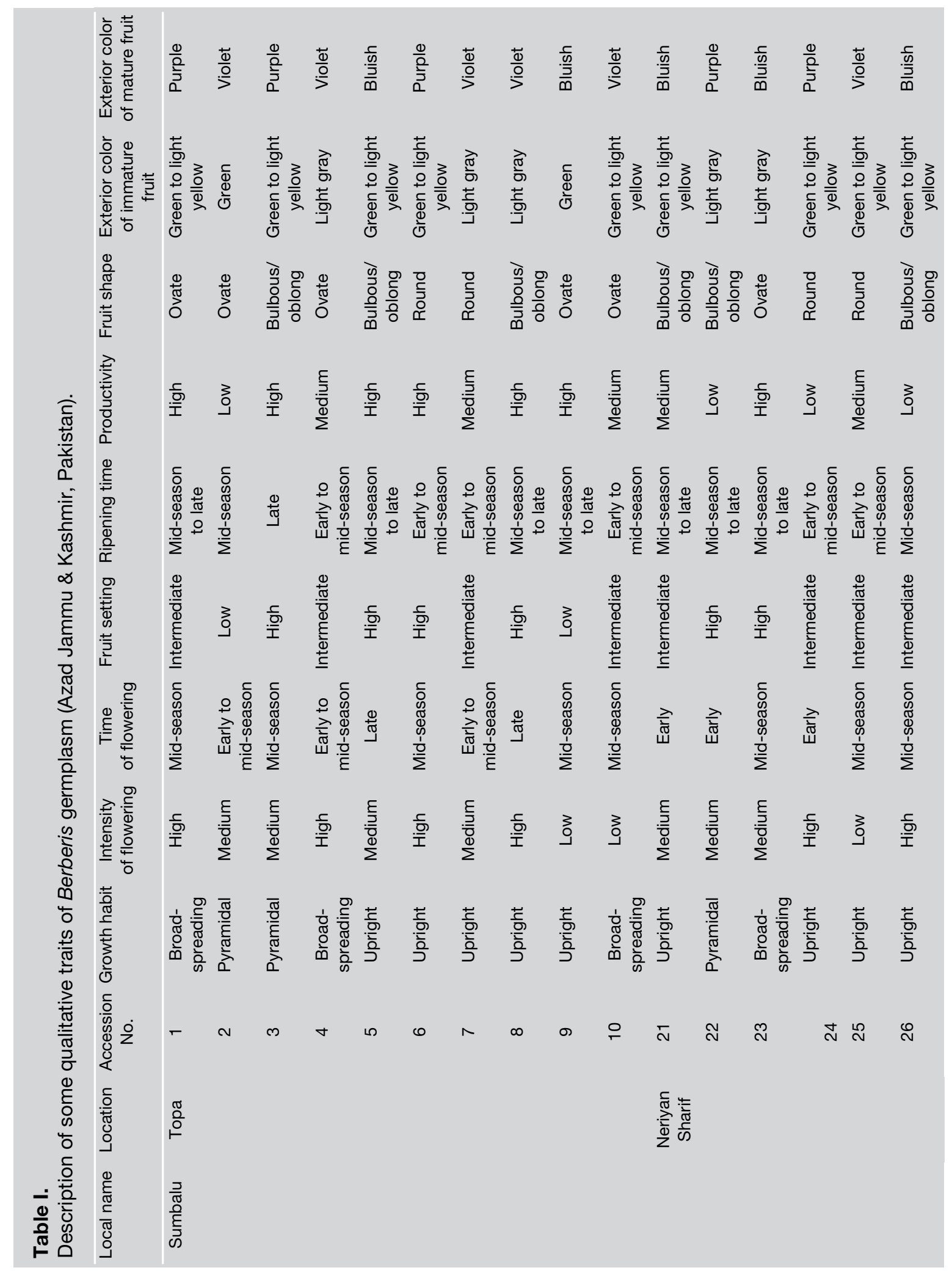




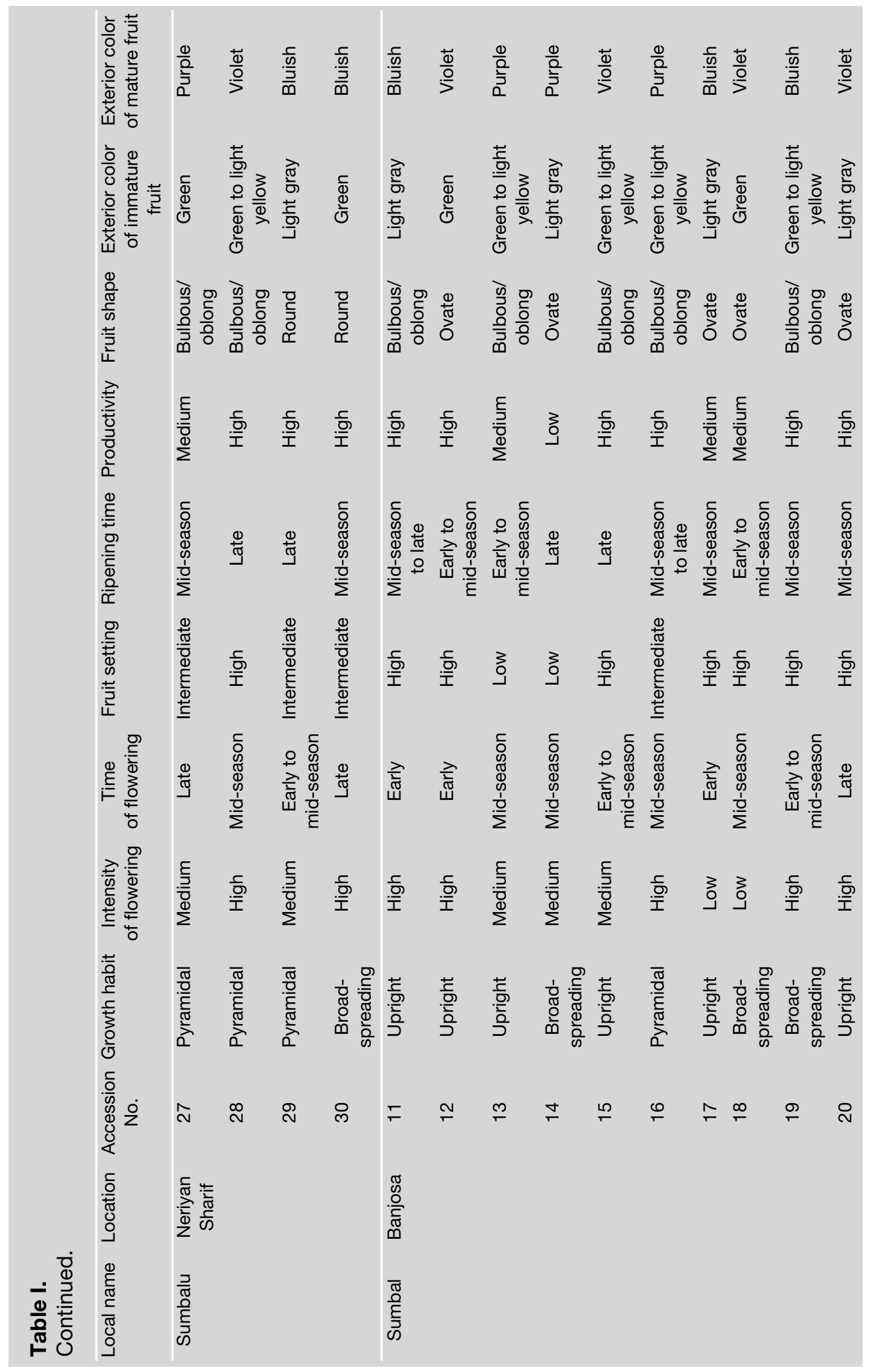

Fruits, vol. 68 (5) 415 


\begin{tabular}{|c|c|c|c|}
\hline Traits & Category & No. of plants & Percentage \\
\hline \multirow[t]{3}{*}{ Growth habit } & Upright & 15 & 50.0 \\
\hline & Pyramidal & 7 & 23.3 \\
\hline & Broad-spreading & 8 & 26.7 \\
\hline \multirow[t]{3}{*}{ Intensity of flowering } & Low & 5 & 16.7 \\
\hline & Medium & 12 & 40.0 \\
\hline & High & 13 & 43.3 \\
\hline \multirow[t]{4}{*}{ Time of flowering } & Early & 6 & 20.0 \\
\hline & Early to mid-season & 6 & 20.0 \\
\hline & Mid-season & 13 & 43.3 \\
\hline & Late & 5 & 16.7 \\
\hline \multirow[t]{3}{*}{ Fruit setting } & Low & 4 & 13.3 \\
\hline & Intermediate & 12 & 40.0 \\
\hline & High & 14 & 46.7 \\
\hline \multirow[t]{4}{*}{ Ripening time } & Early to mid-season & 9 & 30.0 \\
\hline & Mid-season & 7 & 23.3 \\
\hline & Mid-season to late & 9 & 30.0 \\
\hline & Late & 5 & 16.7 \\
\hline \multirow[t]{3}{*}{ Productivity } & Low & 5 & 16.7 \\
\hline & Medium & 9 & 30.0 \\
\hline & High & 16 & 53.3 \\
\hline \multirow[t]{3}{*}{ Fruit shape } & Bulbous/ oblong & 13 & 43.3 \\
\hline & Round & 6 & 20.0 \\
\hline & Ovate & 11 & 36.7 \\
\hline \multirow[t]{3}{*}{ Exterior color of immature fruit } & Green to light yellow & 14 & 46.7 \\
\hline & Light gray & 10 & 33.3 \\
\hline & Green & 6 & 20.0 \\
\hline \multirow[t]{3}{*}{ Exterior color of mature fruit } & Purple & 9 & 30.0 \\
\hline & Violet & 11 & 36.7 \\
\hline & Bluish & 10 & 33.3 \\
\hline
\end{tabular}

only four accessions (13.3\%) had low fruit set (figure 2). Observation regarding the time of ripening was recorded when fruits reached the optimum level of maturity. Nine accessions (30\%) were early- to midseason-ripening. Seven accessions (23.3\%) were mid-season-ripening and nine accessions (30\%) were mid-season to late in their ripening of fruits. The five other accessions (16.7\%) were late-ripening. Sixteen accessions $(53.3 \%)$ were found to be highly productive; nine $(30 \%)$ had a moderate yield, while only five accessions (16.7\%) were low in productivity. For fruit shape, eleven accessions (36.7\%) had ovate fruits, thirteen (43.3\%) had bulbous/oblong fruits, while six accessions had round-shaped fruits. The exterior color of immature fruits was green to light yellow for fourteen accessions (46.7\%), light gray for ten accessions (33.3\%) and green for the remaining six accessions (20\%), while the exterior color of mature fruits was purple for nine accessions (30\%), bluish for ten accessions (33.3\%) and violet for the other eleven accessions (36.7\%). In our study, this diversity might be 

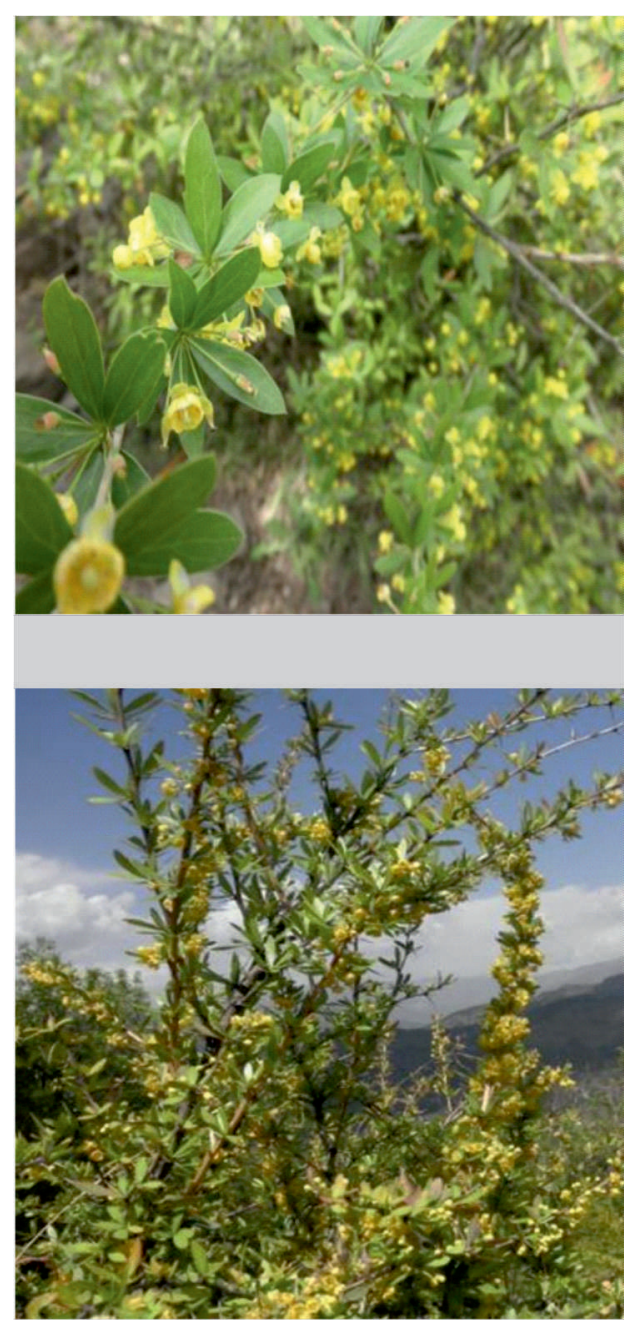

Figure 1.

Flowering stage of Berberis germplasm (Azad Jammu \& Kashmir, Pakistan).

partly due to variations in local conditions such as topography, soil conditions, climate, sunlight, rainfall and other salient features of the location. Plants bloom earlier in warm temperate regions with a southern aspect as plants receive more sunlight than those growing on northern aspects. In the localities where frost occurs during spring and low temperature prevails, plants bloom late.

\subsection{Physical/morphological analysis}

For quantitative parameters of a phenotypi$\mathrm{cal} /$ morphological nature (table III), the

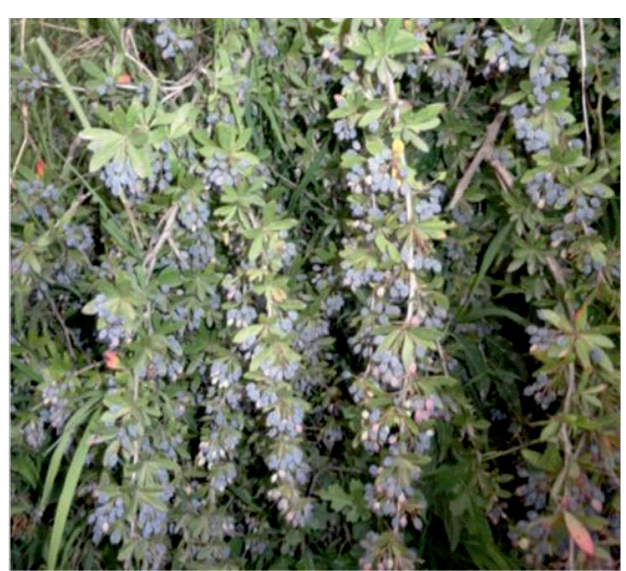

Figure 2.

Fruiting stage of Berberis germplasm (Azad Jammu \& Kashmir, Pakistan).

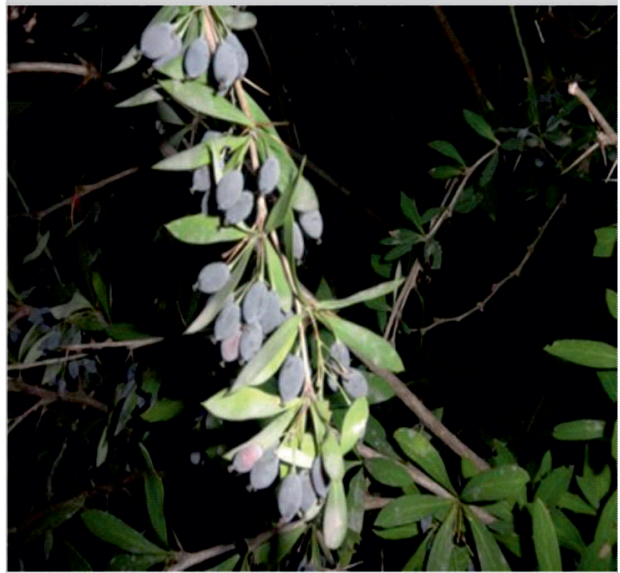

maximum height $(2.117 \mathrm{~m})$ was recorded in the plants growing in the Neriyan Sharif location as compared with those found at the other two locations, i.e., Banjosa $(2.033 \mathrm{~m})$ and Topa $(1.957 \mathrm{~m})$. The maximum number of branches per plant (60.80) was counted in plants grown in Neriyan Sharif. This was followed by the plants found in the Banjosa location ( 57.40 branches per plant), and the minimum number of branches $\quad(54.40$ branches per plant) was recorded in plants of the Topa location. The variations in height and number of branches per plant in barberry are supported by the findings of Zargari [20] and Amin [21], who stated that barberry plants are 1-3 $\mathrm{m}$ tall with 50-60 branches per plant. The differences in the values of these traits at different locations might be partly due to variations in local environments such as sunlight, soil conditions, climate, topography, rainfall and other salient features of the area. Palmer 


\begin{tabular}{|c|c|c|c|c|c|c|c|c|c|c|}
\hline \multirow[t]{2}{*}{ Location } & \multirow{2}{*}{$\begin{array}{l}\text { Plant } \\
\text { height } \\
(\mathrm{m})\end{array}$} & \multirow{2}{*}{$\begin{array}{l}\text { Number } \\
\text { of branches } \\
\text { per plant }\end{array}$} & $\begin{array}{l}\text { Leaf } \\
\text { length }\end{array}$ & $\begin{array}{l}\text { Leaf } \\
\text { width }\end{array}$ & \multirow{2}{*}{$\begin{array}{l}\text { Flowering } \\
\text { duration } \\
\text { (days) }\end{array}$} & \multirow[t]{2}{*}{$\begin{array}{c}\text { Fruit setting } \\
\text { (\%) }\end{array}$} & \multirow[t]{2}{*}{$\begin{array}{l}\text { Days to fruit } \\
\text { maturity }\end{array}$} & $\begin{array}{c}\text { Fruit } \\
\text { length }\end{array}$ & $\begin{array}{l}\text { Fruit } \\
\text { width }\end{array}$ & \multirow{2}{*}{$\begin{array}{l}\text { Fruit } \\
\text { weight } \\
\text { (mg) }\end{array}$} \\
\hline & & & \multicolumn{2}{|c|}{$(\mathrm{cm})$} & & & & \multicolumn{2}{|c|}{$(\mathrm{mm})$} & \\
\hline Topa & $1.957 \mathrm{c}$ & $54.40 \mathrm{c}$ & $9.69 a$ & $3.31 \mathrm{a}$ & $13.40 \mathrm{c}$ & $69.00 \mathrm{c}$ & $30.00 \mathrm{c}$ & $9.75 \mathrm{a}$ & $4.34 \mathrm{a}$ & $122.80 \mathrm{a}$ \\
\hline Banjosa & $2.033 \mathrm{~b}$ & $57.40 \mathrm{~b}$ & $7.09 \mathrm{~b}$ & $2.98 \mathrm{~b}$ & $17.30 \mathrm{~b}$ & $73.80 \mathrm{~b}$ & $33.00 \mathrm{~b}$ & $8.34 \mathrm{~b}$ & $3.45 b$ & $121.20 \mathrm{a}$ \\
\hline Neriyan Sharif & $2.117 \mathrm{a}$ & $60.80 \mathrm{a}$ & $6.67 c$ & $2.58 \mathrm{c}$ & $19.50 \mathrm{a}$ & $78.90 \mathrm{a}$ & $36.40 \mathrm{a}$ & $7.12 \mathrm{c}$ & $2.65 c$ & $115.00 \mathrm{~b}$ \\
\hline LSD $(P \leq 0.05)$ & 0.070 & 0.58 & 0.43 & 0.12 & 0.66 & 0.78 & 0.38 & 0.87 & 0.66 & 1.63 \\
\hline
\end{tabular}

reported that plant height and number of branches are greatly influenced by location, soil and climatic factors [22].

Leaves of the plants collected from different locations exhibited significant difference in their length and width, and those collected from the Topa location were larger in size $(9.69 \mathrm{~cm} \times 3.31 \mathrm{~cm})$ as compared with those from the other two locations. The smallest sized leaves $(6.67 \mathrm{~cm} \times 2.58 \mathrm{~cm})$ were found in those plants growing in the Neriyan Sharif location. Our present observations were strongly supported by the findings of Lone and Wafal, who reported remarkable diversity in leaves and flowers of rosaceous fruits [23]. Genetic as well as environmental factors are responsible for the diversity in leaf size.

The maximum flowering duration (19.50 days) was recorded in the plants growing in Neriyan Sharif and the minimum flowering duration (13.40 days) was recorded in plants of the Topa location. The main reason for differences in flowering duration was probably due to variation in the topography, elevation and mean temperatures of the localities. The highest percentage of fruit set was recorded in plants growing in the Neriyan Sharif location (78.90\%), whereas plants of the other two locations differed in their fruit setting, with significantly lower percentages (table III) Maximum days to fruit maturity (36.40 days) were recorded in plants of Neriyan Sharif, followed by those in Banjosa (33.00 days), and minimum days to fruit maturity (30.00 days) were recorded in the plants of the Topa location. The Berberis germplasm normally varies in its flowering, fruit setting and fruit yields depending upon the prevailing climatic conditions [4]. Fruits mature earlier in warm temperate regions with a southern aspect as plants receive more sunlight than those growing on northern aspects. The productivity of Berberis germplasm depends upon initial fruit set, its retention, and subsequent fruit growth and development, which is influenced by prevailing environmental conditions.

Fruits collected from the Topa location were of large size $(9.75 \mathrm{~mm} \times 4.34 \mathrm{~mm})$ and differed statistically from the fruits of the Banjosa $(8.34 \mathrm{~mm} \times 3.45 \mathrm{~mm})$ and Neriyan Sharif $(7.12 \mathrm{~mm} \times 2.65 \mathrm{~mm})$ locations (table III). The maximum fruit weight (122.8 $\mathrm{mg}$ ) was recorded in the plants found in Topa and in Banjosa (121.2 mg), which did not statistically differ; fruits of Neriyan Sharif had the minimum average weight $(115.0 \mathrm{mg})$. The results indicated variations in fruit size and weight among the plants of different locations. Similar results have been reported by Akbulut et al. [24]. Environmental factors such as temperature, sunlight, rainfall, snowfall and hail storms vary greatly from zone to zone and locality to locality in the State of Azad Jammu and Kashmir, which ultimately affect fruit size and weight [6]. This may be due to plant selection in dense populations, which ultimately causes variations in fruit weight and size at different locations. Similar findings were reported by Garriz et al., who wrote that closer spacing between plants of the same and other species affects the fruit size due to competition for light, nutrition and water [25]. 
Table IV.

Effect of location on chemical composition of Berberis fruits (Azad Jammu \& Kashmir, Pakistan).

\begin{tabular}{|c|c|c|c|c|c|c|c|c|c|}
\hline \multirow[t]{2}{*}{ Location } & Moisture & Carbohydrate & Protein & Fat & Fiber & Ash & \multirow{2}{*}{$\begin{array}{c}\text { TSS } \\
\left({ }^{\circ} \text { Brix) }\right.\end{array}$} & \multirow{2}{*}{$\begin{array}{l}\text { Juice acidity } \\
\text { (\%) }\end{array}$} & \multirow[t]{2}{*}{$\mathrm{pH}$ of juice } \\
\hline & \multicolumn{6}{|c|}{ (\%) } & & & \\
\hline Topa & $59.67 \mathrm{c}$ & $25.33 \mathrm{a}$ & $7.003 \mathrm{c}$ & $3.353 \mathrm{~b}$ & $1.663 \mathrm{c}$ & $5.630 \mathrm{a}$ & $27.63 \mathrm{a}$ & $0.423 \mathrm{c}$ & $4.43 a$ \\
\hline Banjosa & $62.61 \mathrm{~b}$ & $22.71 \mathrm{~b}$ & $9.443 \mathrm{~b}$ & $2.693 \mathrm{c}$ & $2.693 \mathrm{~b}$ & $2.900 \mathrm{c}$ & $25.36 \mathrm{~b}$ & $0.890 \mathrm{~b}$ & $3.75 b$ \\
\hline Neriyan Sharif & $64.70 \mathrm{a}$ & $20.73 c$ & $10.580 \mathrm{a}$ & $4.360 \mathrm{a}$ & $3.533 \mathrm{a}$ & $3.933 \mathrm{~b}$ & $23.60 \mathrm{c}$ & $1.273 \mathrm{a}$ & $3.13 c$ \\
\hline $\operatorname{LSD}(P \leq 0.05)$ & 0.53 & 1.34 & 1.133 & 0.376 & 0.640 & 1.018 & 1.43 & 0.091 & 0.41 \\
\hline
\end{tabular}

\subsection{Chemical analysis}

The results regarding the chemical composition of barberry fruits collected from different locations revealed significant differences $(p<0.05)$ for moisture content, carbohydrate, crude protein, fat, fiber and ash contents of fruit pulp, and total soluble solids (TSS), acidity (\%) and $\mathrm{pH}$ of fruit juice (table IV). The moisture content varied from $59.67 \%$ to $64.70 \%$, being the highest in fruits collected from Neriyan Sharif and the lowest in those from Topa. The differences in moisture content among the fruits collected from different locations might be due to the variation in the amount and distribution of rainfall and other climatic conditions prevailing at these locations. However, the amount of moisture in fruit is an important parameter, as it relates to the juice content of the fruit. The carbohydrate content varied from $20.73 \%$ to $25.33 \%$, being maximum in fruits of Topa and minimum in those collected from Neriyan Sharif. The highest protein content (10.58\%) was recorded in fruits harvested from Neriyan Sharif, then by the fruits sampled from Banjosa (9.44\%), and the minimum protein content $(7.00 \%)$ was found in fruits taken from Topa. However, these mean values of protein content for different locations differed significantly from each other. Fat content varied from $2.69 \%$ in fruits of the Banjosa location to $4.36 \%$ in those harvested from Neriyan Sharif. The highest fiber content (3.53\%) was recorded in fruit sampled from Neriyan Sharif, which was significantly greater than from the fruits harvested from the other two locations. Maximum ash content (5.63\%) was recorded in fruits sampled from Topa, which differed significantly from fruits of the other two locations. The lowest ash content (2.90\%) was weighed in the fruits collected from the Banjosa locality.

The juice extracted from the fruits collected from Topa had the highest TSS and those of Neriyan Sharif had the lowest percentage. As the moisture content of the fruits increased, the TSS value decreased. The fruits collected from Neriyan Sharif were more acidic, with the lowest $\mathrm{pH}$ value of juice as compared with the fruits harvested from the other two locations. The differences in TSS may possibly be due to differences in genotypes, prevailing environmental conditions and also moisture/ juice content of the fruits [26].

\subsection{Mineral composition}

The results regarding the mineral composition of barberry fruits collected from different locations show that the concentrations of $\mathrm{K}, \mathrm{Na}, \mathrm{Fe}, \mathrm{Cu}, \mathrm{Zn}, \mathrm{Pb}$ and $\mathrm{Cr}$ were significantly higher in the fruits collected from the Neriyan Sharif location (table V). This was followed by those harvested from the Banjosa location. The lowest concentrations of these minerals were recorded in fruits taken from Topa. The maximum Ca concentration was also recorded in fruits collected from Neriyan Sharif. However, the minimum Ca concentration was found in fruits harvested from Banjosa. On the other hand, the Mn concentration was significantly higher in the fruits harvested from the Topa location, lower in fruits from the Banjosa location and intermediate in fruits from the Neriyan Sharif location (table V). Knowledge about mineral contents of fruits is very important 
Table V.

Effect of location on mineral composition ( $\mathrm{mg} \cdot \mathrm{kg}^{-1}$ ) of Berberis fruits (Azad Jammu \& Kashmir, Pakistan).

$\begin{array}{lccccccccc}\text { Location } & \begin{array}{c}\text { Potassium } \\ (\mathrm{K})\end{array} & \begin{array}{c}\text { Calcium } \\ (\mathrm{Ca})\end{array} & \begin{array}{c}\text { Sodium } \\ (\mathrm{Na})\end{array} & \begin{array}{c}\text { Iron } \\ (\mathrm{Fe})\end{array} & \begin{array}{c}\text { Copper } \\ (\mathrm{Cu})\end{array} & \begin{array}{c}\text { Zinc } \\ (\mathrm{Zn})\end{array} & \begin{array}{c}\text { Manganese } \\ (\mathrm{Mn})\end{array} & \begin{array}{c}\text { Lead } \\ (\mathrm{Pb})\end{array} & \begin{array}{c}\text { Chromium } \\ (\mathrm{Cr})\end{array} \\ \text { Topa } & 355.00 \mathrm{c} & 93.33 \mathrm{~b} & 475.70 \mathrm{c} & 105.30 \mathrm{c} & 95.23 \mathrm{c} & 1.012 \mathrm{c} & 2.473 \mathrm{a} & 0.640 \mathrm{c} & 0.630 \mathrm{c} \\ \text { Banjosa } & 361.70 \mathrm{~b} & 87.67 \mathrm{c} & 482.70 \mathrm{~b} & 110.00 \mathrm{~b} & 100.50 \mathrm{~b} & 1.288 \mathrm{~b} & 1.860 \mathrm{c} & 0.930 \mathrm{~b} & 0.971 \mathrm{~b} \\ \text { Neriyan Sharif } & 367.00 \mathrm{a} & 97.67 \mathrm{a} & 492.00 \mathrm{a} & 116.30 \mathrm{a} & 103.80 \mathrm{a} & 1.573 \mathrm{a} & 2.017 \mathrm{~b} & 1.083 \mathrm{a} & 1.183 \mathrm{a} \\ \text { LSD }(P \leq 0.05) & 2.84 & 3.58 & 2.01 & 3.41 & 3.06 & 0.117 & 0.084 & 0.045 & 0.029\end{array}$

from a human nutrition point of view Minerals contribute to several biological processes in the body; however, these have not been established as essential sources for a nutritional diet [27]. Variation in the mineral composition of mulberry and wild strawberry fruits has also been reported $[28,29]$. In our present study, the fruits collected from different locations differed in their mineral contents. However, these values are within the range already reported in wild Berberis fruits [24, 30, 31]. The variation in mineral composition of fruits collected from different locations might be due to differences in topography, and soil and climatic conditions of the localities. Sood et al. also stated that genotypic differences, topography, and soil and climatic conditions affect the mineral composition of wild Berberis fruits [14].

\section{Conclusion}

Wild germplasm of barberry was explored from three different geo-ecological locations of Poonch Division of Azad Jammu and Kashmir (Pakistan) and plants were assessed on their qualitative and quantitative parameters. The high variability found in their traits could be helpful for genetic improvement and further evaluation for preservation of these genetic resources. The barberry fruit is a good source of various nutrients, especially carbohydrates, protein, fat, fiber and minerals. Considering their zero cost of production, easy availability, hardy nature and abundant production, they need to be popularized and exploited on a commercial scale. This will help in conserving and managing the natural environment of the area. Further, the integrity of foodchain relationships within the ecosystem can also be maintained.

\section{References}

[1] Chauhan N.S., Medicinal and aromatic plants of Himachal Pradesh, Indus Publ. Co., New-Delhi, India, 1999.

[2] Ali M., Malik A.R., Sharma K.R., Vegetative propagation of Berberis aristata DC. An endangered Himalayan shrub, J. Med. Plants Res. 2 (2008) 374-377.

[3] Sharma B.D., Balakrishnan N.P., Rao R.R., Hajira P.K., Flora of India. Vol. I. Ranunculaceae - Barclayaceae, Botanical Survey of India, Calcutta, India, 1993, pp. 67-411.

[4] Parmar C., Kaushal M.K., Berberis aristata, in: Wild fruits, Kalyani Publ., New-Delhi, India, 1982, pp. 10-14.

[5] Saied S., Batool S., Naz S., Phytochemical studies of Berberis aristata, Univ. Karachi, Dep. Chem., Karachi, Pakistan, 2007.

[6] Chopra R.N., Glossary of Indian medicinal plants, CSIR, New-Delhi, India, 1956, pp. 23-25.

[7] Watt A., Biodiversity in mountain and forest ecosystem spectrum, Brit. Sci. News 232 (1993) 11-14.

[8] Ahmed M., Anjum M.A., Shinwari Z.K., Awan M.S., Rabbani M.A., Assessment of variability in fruit quality parameters of Pyrus germplasm collected from Azad Jammu and Kashmir (Pakistan), Pak. J. Bot. 42 (2011) 971-981.

[9] Khanizadeh S., Rekika D., Ehsani-Moghaddam B., Tsao R., Yang R., Charles M.T., Sullivan J.A., Gauthier L., Gosselin A., Potel A.M., Reynaud G., Thomas E., Horticultural characteristics and chemical composition of 
advanced raspberry lines from Quebec and Ontario, LWT Food Sci. Technol. 42 (2009) 893-898.

[10] Paganova V., Taxonomical reliability of leaf and fruit morphological characteristic of the Pyrus L. taxa in Slovakia, HortSci. 3 (2003) 98-107.

[11] Zaffar G., Mir M.S., Sofi A.A., Genetic divergence among apricot (Prunus armeniaca L.) genotypes of Kargil, Ladakh, Ind. J. Hort. 61 (2004) 6-9.

[12] Maikhuri R.K., Semwal R.L., Singh A., Nautiyal M.C., Wild fruits as a contribution to sustainable rural development: a case study from the Garhwal Himalaya, Int. J. Sustain. Dev. World Ecol.1 (1994) 56-68.

[13] Abbasi M.K., Khan M.N., Introduction of white clover for herbage production and nitrogen fixation in the hilly areas of Azad Jammu and Kashmir, Mountain Res. Dev. 24 (2004) 134-140.

[14] Sood P., Modgil R., Sood M., Physico-chemical and nutritional evaluation of indigenous wild fruit Kasmal, Berberis lycium Royle, Ind. J. Nat. Prod. Resour. 1 (2010) 302-306.

[15] Anon., Colour chart, R. Hortic. Soc., London, U.K., 2001.

[16] Singh S.K., Bist L.D., Patel V.B., Flowering and floral biology studies in low chill pear cultivars, Ind. J. Hort. 61 (2004) 94-96.

[17] Anon., Official methods of analysis (17th Ed.), Assoc. Off. Anal. Chem. (AOAC), Wash. D.C., U.S.A., 2000.

[18] Pearson D., Melon H.K., Ronald S., Chemical analysis of food (8th Ed.), Churchill Livingstone, U.S.A., 1976, pp. 5-63.

[19] Anon., Approved methods of american association of cereal chemists, Am. Assoc. Cereal Chem. Inc. (AACC), St. Paul Minn., U.S.A., 2000.

[20] Zargari A., Medicinal plants, Vol. 1., Univ. Tehran Press, Tehran, Iran, 1983, pp. 96-98.

[21] Amin G., Popular medicinal plants of Iran, Health Minist. Press, Tehran, Iran, 1991, 4447.
[22] Palmer J.W., Computed effects of spacing on light interception and distribution within hedgerow trees in relation to productivity, Acta Hortic. 114 (1981) 80-88.

[23] Lone A.F., Wafal B.A., Varietal diversity in the germplasm of cherries under cultivation in Kashmir, in: Khan M.A., Farooq S. (Eds.), Environmental biodiversity and conservation, A.P.H. Publ. Corp., New-Delhi, India, 2000, pp. 319-340.

[24] Akbulut M., Calisir S., Marakoglu T., Coklar $\mathrm{H}$., Some physico-mechanical and nutritional properties of barberry (Berberis vulgaris L.) fruits, J. Food Process Eng. 32 (2009) 497-511.

[25] Garriz P.I., Colavita G.M., Alvarez H.L., Fruit and spur leaf growth and quality as influenced by low irradiance levels in pear, Sci. Hortic. 77 (1998) 195-205.

[26] Özcan M., Akbulut M., Some physical and chemical properties of myrtle (Myrtus communis L.) fruits, J. Food. 23 (1998) 121-123.

[27] Freland G.J., Grider A., Minerals dietary importance, in: Macrae R., Robinson R.K., Sadler M.J. (Eds.), Encyclopedia of food science, food technology and nutrition, Vol. 5., Acad. Press Inc., San Diego, California, U.S.A., 1993.

[28] Akbulut M., Cetin C., Coklar H., Determination of some chemical properties and mineral contents in different mulberry fruits, II. Ntl. Symp. Berry fruits, Sept. 1416, Tokat, Turkey, 2006.

[29] Akbulut M., Cetin C., Coklar H., Determination of phytochemical properties, antioxidant capacity and mineral contents in wild strawberry fruits, II. NtI. Symp. Berry fruits, Sept. 14-16, Tokat, Turkey, 2006.

[30] Goel B., Kumar A., Composition of uncommon food, J. Food Sci. Technol. 26 (1989) 44-45.

[31] Katiyar S.K., Kumar N., Bhatia A.K., Sharma K., Composition of some unconventional Himalayan wild fruits, J. Food Sci. Technol. 27 (1990) 309-310. 


\section{Caracterización del material genético autóctono del árbol de agracejo en Paquistán: variabilidad de las características morfológicas de la composi- ción nutricional.}

Resumen - Introducción. El árbol de agracejo (Berberis aristata DC.), que produce pequeños frutos, crece en estado salvaje en la zona templada del norte de Paquistán. Material y métodos. Se exploraron tres localidades diferentes (Topa, Banjosa y Neriyan Sharif) de Azad Jammu y Cachemira; se identificaron treinta accesiones de árbol de agracejo según su porte, floración, fructificación y composición química de los frutos. Resultados. Las accesiones estudiadas presentaron una fuerte diversidad de características fenotípicas y morfológicas (porte, intensidad y duración de la floración, cuajado, maduración, productividad, forma y color del fruto). La localización tuvo una gran incidencia sobre los parámetros cuantitativos. Las accesiones recogidas en Neriyan Sharif presentaron plantas significativamente mayores, más ramas por planta, una duración mayor de la floración, un tiempo de maduración más largo y un fuerte índice de cuajado, mientras que los frutos recogidos en Topa tenían hojas mayores y frutos con un peso medio elevado. La composición nutricional de los frutos reveló que las accesiones de Topa producían frutos con mayor contenido en glúcidos, cenizas, sólidos solubles totales y Mn con un zumo de $\mathrm{pH}$ elevado y poca acidez, mientras que los frutos de las accesiones de Neriyan Sharif presentaron índices significativamente mayores de humedad, proteínas lípidos, fibras, $\mathrm{K}, \mathrm{Ca}, \mathrm{Na}, \mathrm{Fe}, \mathrm{Cu}, \mathrm{Pb}$ y contenido en $\mathrm{Cr}$, y eran muy ácidos. Las accesiones recogidas en Banjosa presentaron índices prácticamente intermedios en las características cuantitativas estudiadas. Conclusión. Nuestros resultados sugieren, que, además del genotipo, el lugar de cultivo es un factor principal que determina el porte, la productividad y la composición nutricional de los frutos del árbol de agracejo; estos útiles datos podrían permitir optimizar su uso a nivel global.

Pakistán / Berberis aristata / biodiversidad / frutas / propiedades fisicoquímicas / composición aproximada / interacción genotipo ambiente 